\title{
SOCIOECONOMIC FACTORS INFLUENCING PLANTAIN PRODUCTION IN KHANA LOCAL GOVERNMENT AREA OF RIVERS STATE
}

\author{
Z.A. Elum \& H.D. Tigiri \\ Department of Agricultural Economics, Faculty of Agriculture, University of Port Harcourt, \\ P.M.B. 5323, Choba, Rivers State.Email: zelda.elum@uniport.edu.ng
}

\begin{abstract}
Plantain production in Nigeria is highly constrained by certain socio-economic factors. The study investigated the socio-economic factors influencing plantain production in Khan a local government area of Rivers state. Collected primary data was analysed using descriptive statistical tools and simple linear regression fitting in four functional forms. The results of analysis showed the socioeconomic factors influencing plantain production to include gender, age, household size and farm size. Furthermore, using a four-point type of Likert's scale to measure factors militating against plantain production showed the major challenges to include poor processing and storage facilities, inadequate extension knowledge, unavailability of credit facilities, poor irrigation facilities, high perishability, high incidence of plantain disease and poor marketing system among others. It is suggested that farmers should be assisted through provision of adequate storage and processing facilities as well as loan facilities to enable them acquire necessary farm inputs, hire labour and acquire suitable farmland.
\end{abstract}

Keywords: Plantain, Production, Socioeconomic, Smallholder Farmers, Nigeria.

\section{INTRODUCTION}

Plantain (Musa paradisiaca) is a giant herb that is cultivated in humid forest and mid-latitude zone of sub-Sahara Africa. It is thought to have originated from South East Asia. However, a remarkable diversity of plantain exists in sub-Sahara Africa (Akintade, Okunlola \& Akinbani, 2016).Plantains are sources of starch and energy (Dankyi et al., 2007). Plantain is as well a viable source of income for small scale farmers who grow it in their garden. It is largely planted by small holders and plays a major role in food security and income generation for millions of poor rural regions around the world especially in African and Latin American countries (Babatunde, 2010). Uganda, Colombia, Ghana, Rwanda, Democratic Republic of the Congo and Nigeria are the largest producers of plantain with average yield of 15.7 tons/ha (FAOSTAT, 2017). It is estimated that about 70 million people in West and Central Africa derive more than $25 \%$ of their carbohydrate from plantains (Swennen, 1990). Nigeria is one of the largest plantain producing countries in the world (FAO, 2006). Despite the rapid development of the plantain industry since the early 1960's, Nigeria does not feature among plantain exporting nations because it produces more for local consumption than for export (Akintade et al., 2016; Akinyemi, Aiyelaagbe \& Akyeampong, 2010).

Plantain is predominant in the southern states of Nigeria which include; Akwa - Ibom, Cross River, Imo, Enugu, Rivers, Edo, Delta, Lagos, Ogun, Osun and Oyo states (Ogazi, 1996). These states have annual rainfall usually above $1000 \mathrm{~mm} /$ year, spread over 7 to 9 months. Forest soils in the southern belt of Nigeria are naturally fertile as a result of dense vegetation cover and are good for 
plantain production (Akinyemi et al., 2010). The demand for plantain has increased tremendously over time due to the emergence of local processing industries which use it industrially to make bread and cakes among others (Ekunwe \& Ajayi, 2010). Rise in plantain consumption in Nigeria can also be attributed to rapidly increasing urbanization and great demand for easy and convenient food by the non-farming urban population (Akinyemi et al., 2010).Plantain commercial value chain products include plantain chips (fried unripe), "dodo" (fried ripe), plantain flour and other forms in which it can be consumed (Adetunji \& Adesiyan, 2008). According to Ekunwe and Ajayi (2010), plantain can either be consumed boiled, roasted on heated charcoal or pounded with yam or cassava. Plantain peels are used for livestock feed, while the dried peels are used for soap production. The dried leaves, sheaths and petioles are used as tying materials, sponges and roofing material. Its leaves are also used for wrapping, packaging, and serving of food and for industrial use (Akinyemi et al., 2010). Nutritionally, plantains have good amount of vitamin C and vitamin A. Plantains are rich sources of B-complex vitamins (particularly high in vitamin-B6), folates, niacin, riboflavin and thiamin. In addition, plantains provide adequate levels of minerals such as iron, magnesium, and phosphorous (Jola, 2013).

Furthermore, in spite of the prominence of plantain in Nigeria including Khana local government area (LGA) of Rivers State, there is low productivity of the crop (about 14.9 tonnes per hectare compared to 26.4tonnes/ha obtained in Western Africa) due to challenging issues such as scarcity of labour, marketing constraints, diseases, insufficient capital, inadequate farmland, rural-urban migration and inadequate storage facilities(Adewumi, Ayinde, Falana, \& Olatunji, 2009; Akinyemi et al., 2010; Shaibu, Maji, \& Ogburia, 2012). Farmer's poor knowledge and inability to adopt new agricultural technologies is perceivably affecting their productivity. There are limited studies on socioeconomic determinants of plantain production in Khana LGA. As such, this study intends to provide empirical evidence on socioeconomic (e.g. gender, religion, family, income, farm size, employment, farming experience labour cost, occupational status, interest rate, government policy etc.) determinants of plantain production in the study area. Socioeconomic factors can influence plantain production. For example, age, educational level and extension contact contributes to the farmer's adoption level of innovations capable of affecting productivity. In addition, experience which comes with increasing years of farming can potentially cause a farmer to become competent or efficient in production; reducing cost and enhancing quality that in turn leads to higher profit (Henri-Ukoha et al. 2015). On this background, the broad objective of this study is to examine the socioeconomic factors influencing plantain production, specifically describe the socioeconomic characteristics of the plantain producers and examine the constraints hindering plantain production in the study area This study is expected to provide information useful to future researchers. It will inform appropriate policy formulation towards enhancing plantain farmers' productivity in Rivers State and test a relevant hypothesis.

\section{METHODOLOGY}

The study was conducted in Khana LGA of Rivers State, Nigeria. It has an area of $560 \mathrm{~km}^{2}$ with a population of about 292,924 (Nigerian Population Commission, 2006). A two-stage sampling technique was used in the collection of primary data. In the first stage, 10 communities where plantain was mostly produced in commercial quantity were purposively selected from the 38 communities within the LGA. In the second stage, 8 plantain farmers were surveyed from each community through a snow balling technique due to lack of a sampling frame. Thus, a total of 80 
respondents were surveyed. Data was obtained using structured questionnaire. Data was analysed using descriptive statistical tools such as mean, frequency distribution and percentage as well as a simple linear regression fitting of four function forms (linear, double log, exponential and semi$\log$ ). The lead equation was chosen based on statistical and econometric criteria such as the adjusted R-Square and number of significant variables. Further, a Likert's 4-point scale model was adopted in ranking the constraints faced by farmers. The Likert's weight scale measures were 1(Strongly disagree), 2 (Disagree), 3 (Agree) and 4 (Strongly agree). Any mean greater than 2.5 was seen as significant or a major constraint and vice versa. A cut-off point was established by finding the average attitude score of the farmers for each constraint with the formula:

$\mathrm{X}=\frac{\Sigma x}{n}$

Where $X$ is the mean of attitude test score for the farmers, $\Sigma x$ is summation of rank scores of the farmers for an item and $n$ is the number of farmers that scored the particular item.

The variables used in the study are as follows: $Y=$ Income (in naira); $X_{1}=$ Age of farmers (Years); $\mathrm{X}_{2}=\operatorname{Sex}($ male $=1$ or female $=0) ; \mathrm{X}_{3}=$ Educational level (Number of years); $\mathrm{X}_{4}=$ Farm size (ha); $\mathrm{X}_{5}=$ Household size (Number of people); $\mathrm{X}_{6}=$ Labour (man days); $\mathrm{X}_{7}=$ Farming experience (Ordinal); $\mathrm{X}_{8}=$ Cost of inputs (Fertilizer, manure, plantain sucker, land rent); $\mathrm{U}=$ error term.

Model Specification: Linear: $Y=\beta_{0}+\beta_{1} X_{1}+\beta_{2} X_{2}+\beta_{3} X_{3} \ldots \ldots \ldots \ldots \beta_{n} X_{n}+e$

Semi-Log: $Y=\beta_{0}+\beta_{1} \log X_{1}+\beta_{2} \log X_{2}+\beta_{3} \log X_{3} \ldots \ldots \ldots \ldots \beta_{n} \log X_{n}+e$

Exponential: $\log Y=\beta_{0}+\beta_{1} X_{1}+\beta_{2} X_{2}+\beta_{3} X_{3} \ldots \ldots \ldots \ldots{ }_{n} X_{n}+e$

Cob-Douglas: $\log Y=\beta_{0}+\beta_{1} \log X_{1}+\beta_{2} \log X_{2}+\beta_{3} \log X_{3} \ldots \ldots \ldots B_{n} \log X_{n}+e$

Where, $\beta_{0}=$ Intercept, $\beta_{1}, \beta_{2}, \beta_{3} \ldots \ldots \ldots . \beta_{\mathrm{n}}=$ Estimated coefficients and $e$ is an error term

\section{RESULTS}

\section{Socioeconomic characteristics of the plantain producers}

It was observed that majority of the farmers were males $(61.3 \%)$ and were married $(66.3 \%)$. The mean age of the respondents was 55 years, implying that many of the farmers on average were in their active years and therefore in position to effectively and efficiently utilize available resources towards optimum production of plantain. It is seen that the average household size was of 5 persons indicating moderate-sized households. The findings also revealed that $51.3 \%$ of the farmers had secondary school education, implying that most of the plantain farmers are educated and would be amenable to adopt new innovations that can boost plantain production. The study shows the average farm size to be 0.55 ha which indicates that the farmers are predominantly smallholder farmers who are likely limited in scope of operation and production. The mean farming experience of 18.3 years indicates that the plantain farmers have acquired significant experience on the farm and are likely to know the right measures to take to enhance production. It is further observed that the average annual farm income of the plantain farmers is $\$ 99,443 /$ ha and $43 \%$ of the farmers used family labour of $4 \mathrm{man} /$ days annually. It was observed that $98.8 \%$ of the farmers had no contact with extension agents and this could contribute to the farmers' poor knowledge of improved technology. The result agrees with the findings of Akinyemi et al. (2010) that inadequate 
knowledge of improved practices and inefficient system of extension services in plantain production contribute to the low yield potential of the crop in Nigeria.

\section{Socioeconomic determinants of plantain production}

It is seen in Table 2 that the linear function gave the best fit of the four functional forms based on the number of significant coefficients and the magnitude of the $\mathrm{R}^{2}$. The $\mathrm{R}^{2}$ value is $51 \%$ which indicated that $51 \%$ of the variation in income of plantain farmers was accounted for by the various independent variables in the model while the remaining $49 \%$ was due to the error term. The result showed that the gender variable has negative and statistically significant influence on the farmer's income. This implied that male farmers received less income than the females in plantain production. Age had a statistically significant and positive influence on plantain production at 5\% level of significance. This meant that for every yearly increase in the farmer's age, income increases by 934.71. This result agreed with the findings of Kainga and Seiyebo (2012) that farmer's age can greatly influence plantain production. Farm size for plantain production had a positive coefficient that is statistically significant at $1 \%$ level of significance. This implied that a hectare increase in the farm size cultivated by the plantain farmers increased farmer's income by $\$ 98,827$.

\section{Constraints hindering plantain production in the study area}

Several challenges (e.g. high cost of inputs, lack of good roads, issues of land tenure, inadequate extension service, etc.) have been identified in the production and marketing process of plantain. The challenges faced by the plantain farmers are presented in Table 3. It was observed that poor processing and storage facilities ranked first as the most important constraint with a mean value of 3.24. This was followed by inadequate extension knowledge, unavailability of credit facilities, poor irrigation facilities, high perishability, high incidence of plantain disease, high incidence of pest infestation, inadequate finance, long distance between market and farm, poor marketing system, low market price, unavailability and high cost of improved suckers and high cost of inputs. The result supports past studies (Amusa, Enete \& Okon, 2011; Henri-Ukoha et al., 2015) that have documented that lack of improved processing and inadequate storage technologies have resulted in high rate of perishability of the product. More so, the land tenure system practiced in Nigeria has been partly responsible for farmers' lack of interest in acquiring lands for agricultural production. In addition, limited access to credit facilities have reduced Nigeria's smallholder farmers' productivity to a great extent and the lack of/or poor marketing system also discourages them from production (Mgbenka \& Mbah, 2016). The result also conforms to the findings of Akinyemi et al. (2010) who found some of the variables as constraints to plantain production in Nigeria. Similarly, Dankyi et al. (2007) noted plantain production constraints to include inadequate farm size, poor fertility of land, land fragmentation, wrong use of fertilizer, high cost of fertilizers, poor education, high cost of improved suckers, credit, labour, disease, low output price and lack of extension agents' contact. However, this study result showed high cost of labour, cost of land acquisition, lack of manpower, poor access road and issues of land tenure and fragmentation ranked as minor constraints in plantain production. In the view of Arikpo et al. (2009), if the constraints associated with plantain production are tackled, it could lead to increased production and income for stakeholders. 


\section{CONCLUSION}

The study examined the socioeconomic determinants of plantain production in Khana LGA, River state, specifically describing the farmers' socioeconomic characteristics and identifying the constraints faced by the farmers. The study found that the significant factors influencing income from plantain production include gender, age, household size and farm size while the major challenges faced by the farmers included poor processing and storage facilities inadequate extension knowledge, unavailability of credit facilities, poor irrigation facilities, high perishability, high incidence of plantain disease, high incidence of pest infestation and inadequate finance among others. The study therefore suggests that farmers should be assisted with credit facilities by the government or private organisations to enable them acquire necessary improved farm inputs, hire labour, and acquire suitable farmland for optimum production. In addition, adequate storage and processing facilities should be made available to reduce post-harvest spoilage and wastage. 


\section{REFERENCES}

Adewumi, M.O., Ayinde, O.E., Falana O.I. \& Olatunji, G.B. (2009). Analysis of post-harvest losses among plantain/banana (Musa Spp.L.) marketers in Lagos State, Nigeria. Nigerian Journal of Agriculture, Food and Environment. 5(2-4):35-38.

Adetunji, M.O. \&Adesiyan, I.O. (2008). Economic Analysis of plantain marketing in Akinyele local government area of Oyo state, Nigeria. International Journal of Agricultural Economics and Rural Development, 1(1), 15-21.

Akintade, F., Okunola, J. Olaniyi \& Akinbani, A. (2016). Factors influencing adoption of plantain improved technology among small holder farmers in Edo state, Nigeria. Journal of Biology, Agriculture and Health Care, 6(6), 2224-3208.

Akinyemi, S.O.S., Aiyelaagbe, I.O.O. \& Akyeampong, E. (2010). Plantain (Musa spp.) cultivation in Nigeria: a review of its production, marketing and research in the last two decades. Acta Horticulture, 879, 211-218. Doi: 10.17660/actahortic.2010.879.19

Amusa, T. A., Enete, A. A., \& Okon, U. E. (2011). Socioeconomic determinants of cocoyam production among small holder farmers in Ekiti state, Nigeria. International Journal of Agricultural Economics \& Rural Development, 4(2), 97-109.

Arikpo, J.D., Adinya, A.B., Angba, O. Agbogo, E.A, Ahong, E.A., Nyienakuna, M.G., Eze, A.N. \& Ogar, N.E. (2009). Economic Analysis of variables affecting the affecting the plantain (Musa spp) monocropping system of production by small scale farmers in central cross Rivers State, Nigeria. Journal of Agriculture, Forestry and the Social Science, 7(2), 22-30.

Dankyi, A.A., Dzomeku B.M, Anno-Nyako F.O, Adu-Appiah, A. \&Gyamera-Antwi (2007). Plantain production practices in the Ashanti, Brong-Ahafo and Eastern region of Ghana. Asian Journal of Agricultural research, 1(1), 1-9.

Ekunwe, P.A. \& Ajayi, H.I. (2010). Economics of plantain production in Edo state, Nigeria. Research Journal of Agricultural \& Biological Sciences, 6(6), 902-905.

FAOSTAT (2017). Nigeria: Plantains, production quantity (ton). Available at: http://www.factfish.com/statistic-country/nigeria/plantains,+production+quantity

Henri-Ukoha, A., Anaeto, F. C., Chikezie, C., Ibeagwa, O. B., Ukoha, I. I., Oshaji, I. O., \& Anyiam, K. (2015). Analysis of cassava value chain in Ideato South Local Government area, Imo State, South-East Nigeria. International Journal of Life Sciences, 4(4), 209-215.

Kainga, P.E. \& Seiyebo, I.T. (2012). Economics of Plantain production in Yenagoa Local Government Area of Bayelsa State. Journal of Agriculture and Social Research. 12 (1), 114 -123.

Mgbenka, R. N. \& Mbah, E. N. (2016). A review of smallholder farming in Nigeria: Need for transformation. International Journal of Agricultural Extension and Rural Development Studies, $3(2), 43-54$.

National population commission (2006). Report of Nigeria's National Population. Abuja, Nigeria. 
Ogazi, P.O (1996). Plantain: production, processing and utilization. Paman and Associates limited Uku-Okigwe. American Journal of Food Science and Technology, 2 (3), 80-87.

Shaibu, A.A., Maji, E.A. \& Ogburia, M.N. (2012). Yield evaluation of plantain and banana landraces and hybrids in humid agro ecological zone of Nigeria. Journal of Agricultural Research and Development, 2(3), 074-079.

Swennen, R. (1990). Plantain cultivation under West African conditions. A Reference Manual, 1(1), 55-67.

Journal of the Faculty of Agriculture and Veterinary Medicine, Imo State University Owerri website: www ajol.info 
Volume 16 Number 2, October 2018 pp $107-1.16$

Table 1: Socioeconomic characteristics of surveyed farmers $(\mathbf{N}=80)$

\begin{tabular}{|c|c|c|}
\hline Variables & Percentage & Mean \\
\hline \multicolumn{3}{|l|}{ Gender } \\
\hline Male & 61.3 & \\
\hline Female & 38.8 & \\
\hline \multicolumn{3}{|l|}{ Marital status } \\
\hline Married & 66.3 & \\
\hline Single & 11.3 & \\
\hline Divorced/single/separate & 22.6 & \\
\hline Age & & 54.76 \\
\hline Household size & & 5.34 \\
\hline \multicolumn{3}{|l|}{ Educational level } \\
\hline Non-formal education & 12.5 & \\
\hline Primary education & 21.3 & \\
\hline Secondary education & 51.3 & \\
\hline Tertiary education & 15.0 & \\
\hline Farm size & & 0.55 \\
\hline Farming experience & & 18.30 \\
\hline Annual income & & 99443.75 \\
\hline \multicolumn{3}{|l|}{ Labour source } \\
\hline Family labour & 43.8 & \\
\hline Hired labour & 12.5 & \\
\hline Both family and hired & 42.6 & \\
\hline \multicolumn{3}{|l|}{ Number of labour used } \\
\hline $2-4$ & 76.4 & \\
\hline 5 and above & 19 & \\
\hline \multicolumn{3}{|l|}{ Extension agent contacts } \\
\hline Yes & 23.8 & \\
\hline No & 76.3 & \\
\hline
\end{tabular}

Source: Field work 2018.

Journal of the Faculty of Agriculture and Veterinary Medicine, Imo State University Owerri website: www ajol.info 
Volume 16 Number 2, October 2018 pp $107-116$

Table 2: Estimates of four-functional forms of least squares regression analysis

\begin{tabular}{lcclllllll}
\hline Variables & Linear function & Exponential & \multicolumn{3}{c}{ Semi-log } & \multicolumn{3}{c}{ Double log } \\
\hline & Coefficient & t-ratio & Coefficient & t-ratio & Coefficient & t-ratio & Coefficient & t-ratio \\
Constant & 22003.9 & 0.9988 & 9.51331 & $8.639^{* * *}$ & -201234 & -1.283 & 6.87694 & 1.037 \\
Gender & -25204.5 & $-3.342^{* * *}$ & -0.617217 & -1.637 & -5306.49 & $-2.822^{* * *}$ & -0.137163 & $-1.725^{*}$ \\
Marital & 5863.18 & 0.7688 & -0.139287 & -0.3654 & 2655.65 & 1.365 & -0.0162630 & -0.1976 \\
Status & & & & & & & & \\
Age & 934.11 & $2.176^{* *}$ & 0.00754388 & 0.3514 & 52231.1 & $1.803^{*}$ & 0.102971 & 0.08406 \\
$\begin{array}{l}\text { Household } \\
\text { size }\end{array}$ & -4393.91 & $-1.785^{*}$ & -0.0483265 & -0.3929 & -27329.7 & $-2.238^{* *}$ & -0.218561 & -0.4232 \\
Edu. level & 885.449 & 1.096 & 0.00752531 & 0.1863 & 668.286 & 0.3262 & 0.00172735 & 0.01994 \\
Experience & -18.7156 & -0.03692 & 0.00434358 & 0.1714 & -11886.6 & -1.095 & -0.100850 & -0.2198 \\
Farm size & 98827.8 & $7.873 * * *$ & 0.0663963 & 1.058 & 29194.9 & $5.027 * * *$ & 0.129005 & 0.5252 \\
Total cost & 0.441435 & 0.3650 & 2.08006 & 0.3441 & 16872.8 & 1.100 & 0.193859 & 0.2987 \\
$\begin{array}{l}\text { Labour } \\
\text { cost }\end{array}$ & 3952.05 & 0.9353 & 0.384089 & $1.823 *$ & 36170.7 & $1.975^{*}$ & 2.06750 & $2.670^{* * * *}$ \\
\hline
\end{tabular}

$* * *, * *$ and $*$ indicates statistical significance at $0.01,0.05$ and 0.10 level respectively.

Source: Field work 2018.

Journal of the Faculty of Agriculture and Veterinary Medicine, Imo State University Owerri website: www ajol.info 
Volume 16 Number 2, October 2018 pp $107-1.16$

Table 3: Challenges faced in plantain production

\begin{tabular}{ll}
\hline Problems & Mean \\
Poor processing and facilities storage & 3.24 \\
Inadequate extension knowledge & 3.23 \\
Unavailability of credit facility & 3.23 \\
Poor irrigation facilities & 2.96 \\
High perishability of plantain & 2.91 \\
High incidence of plantain disease & 2.88 \\
High incidence of pet infestation & 2.79 \\
Inadequate finance & 2.79 \\
Long distance from market to farm & 2.78 \\
Poor marketing system & 2.73 \\
Low market prices & 2.70 \\
Unavailability and high cost of improved suckers & 2.58 \\
High cost of inputs (organic fertilizer etc.) & 2.55 \\
High cost of labour & 2.33 \\
High cost of land acquisition & 2.16 \\
Lack of manpower & 2.06 \\
Issues of land tenure and fragmentation & 1.66 \\
\hline Poor access road & 1.56 \\
\hline
\end{tabular}

Source: Field work, 2018

Journal of the Faculty of Agriculture and Veterinary Medicine, Imo State University Owerri website: www ajol.info 